\title{
The Relevancy of Teaching Method in Teaching Reading Comprehension with Syllabus and Lesson Plan A Case Study in Junior High Schools in Perbaungan.
}

\author{
Menry Tampubolon \\ Dinas Pendidikan Serdang Bedagai \\ tampubolonmenry@yahoo.co.id
}

\begin{abstract}
This study aims to describe the relevancy of teaching method in teaching Reading Comprehension with Syllabus and Lesson Plan in Junior High Schools in Perbaungan. The relevance that used is the relevance of an assumption to a context. The subjects of this study are the five English teachers of four Junior high Schools in Perbaungan. The instruments for collecting data used are : observations, treatment and the method of this study is qualitative research method. The data was taken after giving treatment. After conducting the research, it was found that two teachers used KWL Method in teaching Recount text, one teacher used PORPE Method in teaching Narrative text and they applied their teaching methods in teaching learning process in teaching Reading Comprehension are relevance with Lesson Plan and Syllabus result the students' achievement in reading comprehension is high and above KKM ( Kriteria Ketuntasan Minimal / Minimal Completeness Criteria), one teacher applied his teaching method in teaching learning process in teaching Reading Comprehension is not relevance with Lesson Plan and Syllabus and one teacher did not apply a teaching method in teaching learning process in teaching Reading Comprehension.
\end{abstract}

Key words : Relevancy, Teaching Method in Teaching Reading Comprehension, Syllabus, Lesson Plan.

\section{Introduction}

Language is a system of communication based upon words and the combination of words into sentences. It is a code used to express and communicate all purposes that needed by the language users. In addition Sapir (1921) says that "language is a purely human and non instinctive method of communicating ideas, emotion and desires by means of a system of voluntarily produced symbols, commonly symbols are represented by words" ( p.7). Based on the definition above, it seems that there is an emphasis on the components of language such as vocabulary, reading, listening and aspects of language. Therefore, the language would be very useful if it is communicated with others to get the meaning of language itself.

To understand the language, It can be said that one must be able to comprehend the text. The language users have to invent the meaning of the words as many as possible either in a sentence at least. By knowing the meaning of the words, one would be able to get the idea from the reading text. Jack C. Richards and Theodore S. Rodgers ( 1986) suggest an English teacher as the classroom teacher and the program coordinator can choose methods and materials according to the needs of learners, the preferences of teachers, and the constraints of the school or educational setting to finding more efficient and more effective ways of teaching languages. Davis (1997: 2 ) suggests that the design and selection of teaching methods must take 
into account not only the nature of the subject matter but also how students learn.. It means that it is very important for teachers to apply planned methods of teaching to maintain effective teaching.

In the English curriculum, the government has regulated how to treat English as a foreign language, which must be mastered well by all students. More over Gurning (2008) states in his journal that the development of curriculum should take into account the kind of literacy. Therefore in the teaching and learning process, the teachers are also expected to be able to teach English well and the students are expected to learn and practice English fluently, good at listening, speaking, reading and writing. Therefore English teacher should have good performance in teaching English so that the students would understand what he / she is going to teach at that time. The performance of a teacher plays an important role in the teaching and learning process because as a teacher he / she has many functions in education. He / She would be acted as an educator, a manager of the class, a guide or a facilitator, a motivator and a stimulator and also a researcher or as an informant.

A teacher could be a producer because he / she produces a lesson plan which is arranged based on the syllabus stated by the government and he / she must be able to manage the teaching learning process, facilitates the students in learning and guide them to use many supported learning circumstances. He / she gives motivation to his / her students and observes the willingness of students. It can be said that the teacher should serve the students as sincerely as possible. It is connected with the motivation of the teacher what goals that they want to achieve : as Gardner states motivation presents a schematic representation of this model. There are four sections, external influences, individual differences, language acquisition contexts, and outcomes. In the socio-educational model, motivation to learn the second language includes three elements. First, the motivated individual expends effort to learn the language. Second, the motivated individual wants to achieve a goal. Third, the motivated individual will enjoy the task of learning the languages. ( 2001 ). As a language teacher, he / she must make decisions at all time. Some of the decisions made are relatively minor ones should be assigned that particular day, for instance other decisions have more preformed implications. What should be the goal of language instruction ? Which language teaching method will be the most effective in reaching it?

However many teachers mostly do not care about the relevance of the teaching method with syllabus and lesson plan while they are teaching in the classroom. They just think that their duty is just to finish the contents of the curriculum instructed by the government, therefore some students cannot grasp the aim of the teaching process. In fact as a good teacher, he/ she should prepare their lesson plan well in order to support their performance in the process of teaching learning especially when the teacher wants to teach reading $\mathrm{He}$ or she should arrange the lesson plan well because in teaching reading the students need to master the vocabulary and to grasp the main idea of the text so that the students get information as much as possible through reading itself.

The Lesson plan is a teacher's guide to do the learning process in class, laboratory and every teaching learning take place. It has a basic competence. Because of that, all points that have been written down in lesson plan covers directly the learning activity in order to achievethe basic competence mastering. Every teacher should make a plan and arranged their teaching and learning before he / she teaches the students. Planning is an anticipatory decision making. It involves deciding what to do, how to do and when to do something. By making the lesson plan, the teacher would have some advantages in the teaching learning process such as :

1. The aim of the lesson which is identified and maintained.

2. The lesson material which is selected and arranged in a logical manner.

3. An instructional method and technique which is selected appropriate to the learning task and the needs of the students.

4. The students who are involved largely in the teaching learning process. 
5. The time of the teaching learning process could be managed properly.

Kurikulum Tingkat Satuan Pendidikan ( KTSP ) or School-Based Curriculum gives autonomy to schools to develop and manage their syllabuses themselves based on the standard suggested in the curriculum and under the supervision of the local government. Before the teacher arranges the lesson plan, he / she should arrange school syllabus based on the Competence Standard (Standar Kompetensi ), The basic competence ( kompetensi dasar), the material, the procedure of teaching learning process, indicators, assessment, time allocation and the source.

The syllabus is elaborated by the teacher himself / herself or done by the same lesson in that school or done by the teachers from many different schools but have the same vision and the unity of subject matter . The teacher is the key agent to apply the syllabus become a lesson plan as authentic program. The best teacher should arrange and prepare the lesson plan well, so that the process of teaching learning would be relevance with the teacher's performance. Relevance as an Explanation of Communication. Roberts ( 1991: 455 ) defines that There are three kinds of relevance, they are : 1 . the relevance of an assumption to a context 2. The relevance of an assumption to an individual and 3. The relevance of phenomenon to an individual.

However many teachers teach the students without preparing the tools of the process teaching learning and it can also occur in junior high schools in Perbaungan. The researcher as a supervisor of Junior high school English teachers in Serdang Bedagai has responsibility to analyze the problem of English teachers especially in Perbaungan and then tries to overcome.

The results of this research are expected to be significant theoretically and practically for education field. Theoretically the result of the research can provide new contribution to the teachers' teaching method and development of the conceptual knowledge about the significance of lesson plan in the process of teaching Reading comprehension. While practically, after conducting the research, the researcher hopes that the research could contribute to the English teacher as a pattern to develop their lesson plan and self reflection to consider the importance of contribution of syllabus and lesson plan in the teaching reading comprehension so that it has relevance with the performance of English teachers. More over the principal of the school could easily develop his / her teachers' knowledge to arrange the syllabus and lesson plan that stated by the government. As the supervisors of the education would be more easily to observe the teachers' activity and could help the teachers to reconstruct the teachers' performance and to improve the qualified lesson plan so that there is a gradual improvement of the quality of the teaching learning process.

\section{General Concept of Reading}

There are various definition of reading from educators, psychologists, linguist and sociologists to have filled volume with their definition of reading. The definition of reading used here is adapted from Anthony, Pearson, and Raphael (1993) as cited by Farrell (2009: 20) in which reading is the process of constructing meaning through the dynamic interaction among the reader's existing knowledge, the information suggested by the written language, and the context of reading situation.

\section{The Nature of Reading Comprehension}

Anderson, ( $2003: 67$ ) divides the process of reading into three models: bottom-up, top - down models, and interactive models as the focus of this study. First, bottom- up is a process where readers begin with smaller element and build up comprehension of what is being read. It is a reading activity to recognize and analyze words and then to build up the grammartical structure, sentences and longer texts. The second, top- down as a process of reading where the reader begins with the larger elements and works down towards smaller elements to build comprehension of what is being read. It means that reader begins with their background knowledge in understanding a text makes prediction and searches the text to confirm or reject the predictions which are already made. The third interactive model of reading as most comprehensive description of reading process. It is a combination of top - down and bottom - up processing.

Published by English Lecturers and Teachers Association (ELTA)

Copyright (C) 2021, authors 


\section{The Process of Reading Comprehension}

Making sense of text can occur in one point therefore the process of it would be before, during and after reading. The process occurs before reading or pre-reading process covers some aspects such as previewing, predicting, setting the purpose and choosing appropiate teaching method. Previewing a text can be done by looking at the title, picture, diagram or graphic in order to remind and activate memories, experiences or schemata. Then predict the text based on previewing in order to help understanding the text. After predicting, find the purpose of reading and the last, choose the appropiate teaching method related to the purpose of the text. As a result, reading comprehension is a complex process since it needs more than activity relationship that, reading comprehension is conceived of four conceptions, they are: 1)transmission, 2)translation, 3)interaction, and 4)transaction

( McNeil, 1992).

\section{The Teaching Method}

A teaching method comprises the principles and methods used for instruction to be implemented by teachers to achieve the desired learning in students. In teaching learning process, teaching method are needed to create condusive atmosphere. The condusive atmosphere will make students feel comfort in learning. A method of teaching is a system for teaching of a language that is based on either a particular theory of language or a particular theory of learning, or usually on both (Thornbury, $2005: 131$ ). It is the way of teaching which is based on the theory of language and learning.

Teaching method is the way of teaching based on the theory of language and the theory of learning and usually based on both theory of language learning by which what is believed to be going to be taught that is linguistically called the approach of the method. It is called method if it has proper procedure to apply or it is sometimes called techniques or in other words as the actualization of theory to practice.

\section{The Method in Teaching Reading Comprehension}

A reading method is a set of teaching and learning materials and/or activities often given a label, such as phonic method, literature based method, or language experience method (international reading association, 1999). The statements say that there is no single method or single combination methods that can successfully teach all students to read. Therefore a teacher / a lecturer must have a strong knowledge of multiple methods for teaching reading and a strong knowledge of the students in their care so they can create the appropriate balance of methods needed for the students they teach. (international reading association, 1999).

Although there is no single method or single combination methods that can successfully teach all students to read, it is still essential for teaching reading experts to conduct studies and invent better methods to revise the old ones. As a result, methods have been found and implemented in reading subject in classroom.

\section{1) Choral Reading (CR) Method}

Choral Reading means reading out loud with your child, the same text at the same time (Wood, 2006 : 216 ). You read together in unison, and your child gets to hear your voice, guiding and supporting.

To prepare, each student reads the whole selection that is going to be chorally read. One can read it aloud and the others following along silently. Then the readers read the piece together. A few repetitions are necessary to fix the piece in the students' thought

\section{2) Paired Reading (PR) Method}

Paired reading is a technique that parents can use to help their own child with reading practice ( Topping, 1995 ). The method involves the parent who is a skilled reader and the child who is learning, reading a book together. According to Koskinen andBlum ( 1986 ), Paired reading is repeated reading, students work with a partner to readshort self-selected passages of text with the goal of improving fluent reading 
Teachers give students opportunities to watch others demonstrating the role of the reader, then the role of the listener, and finally practice the procedure while the teacher watches. After students have had the opportunity to watch and practice these activities, they are usually successful on their own.

\section{3) PORPE Method}

The PORPE method suggested by Simpson and Stahl ( 1989 ). PORPE is a method to study textbook materials in which the students create and answer essay questions

There are five steps in this learning strategy.

1) Predict : After reading the chapter, students predict possible essay questions from the information contained in the text. In the arrangement of these questions, the students should evade questions that begin with "what, who, or when and do not include analysis.

2) Organize: After predict and get the question from information in the text, the teacher asks students to organize or summarize by using their own words.

3)Rehearse : The teacher asks students to recite aloud information after they had summarized, The students have to share information that they get from the text.

4) Practice: The teacher asks students to answer their predicted question before.

5) Evaluate: Teachers evaluate the students' work by asking the following question: Do have enough clear examples? Is my answer complete, truthful, and suitable?

\section{4) KWL Method}

an instructional method known as K-W-L, developed by Ogle (2006) has been implemented in classrooms. Students' prior knowledge is activated by asking them what they already know; then students set goals focusing on what they want to learn, and after reading, students discuss what they have studied. KWL is aimed to be an exercise for a study group or class that can direct the students in reading and understanding a text. The students can adjust it to working alone. The method is formed of only three stages that reflect a worksheet of three columns with the three letters.

1). K stands for Know. This first stage occasionally astonishing: Think first what the students understand about the topic and make a list about that. This activity constructs a knowledge of the new material. Build a scaffold to support it.

2). W stands for Will or Want. The second stage is to list a series of questions of what the students want to know more of the subject, based upon what the students listed in K.

3). L stands for Learned. The final stage is to answer the students' questions, as well as to list what new information the students have learned. Either while reading or after the students have finished.

\section{5) SQ4R Method}

SQ4R is a systematic method of reminding students how to learn from text with maximum effectiveness (Thomas \&Robinson: 1972). This SQ4R Method is very practical to help students keep studying organized and efficient. According to Thomas \&Robinson (1972: 10) the steps to SQ4R are Survey, Question, Read, Recite, Record, and Review.

1) Survey : Students should skim and scan the chapter. The purpose of surveying the chapter is to get the general idea of the content, structure, organization, and plan of the chapter. Surveying the chapter gives the "big picture" a framework of the main ideas, which will help to hold the details together later ( Richardson \& Morgan, 1997: 124 ).

2) Question : Having students develop questions gives them a purpose for reading. Reading for specific purposes positively influences. Setting a purpose also aids the student in recalling information. Developing questions prior to reading results in spontaneous attempts to answer the questions based on information already known, increased concentration and attention while reading to find an answer to the question, and increased comprehension due to the mind in its attempt to find an answer to the question.

Published by English Lecturers and Teachers Association (ELTA)

Copyright (C) 2021, authors 
3) Read : Reading promotes an active search for answers to the specific questions that students have developed. It forces the student to concentrate for better comprehension and aids in lengthening attention span (Richardson \& Morgan, 1997). Students should read each section of the text to answer questions that were developed in the step above. If a word meaning is not clear through its use in the selection, reread. If it is still unclear, underline the word or jot it down and look it up when students finish reading.

4) Recite : Recite the main ideas, in other words, aloud or to the students, after finishing a page. Check the comprehension and make sure the students have the correct information. By reciting what the students' read, the students are able to see how much information the students absorbed, areas the students didn't understand and need to review, and answers to the questions the students generated for the students. If the students cannot answer the questions, go back to the material and reread.

5) Record : Marking the textbook increases understanding of the material for the present and for future reference. The process of selecting and marking requires the students to find the main ideas. The students might use the following: a double underline for main ideas and a single underline for supporting points; a bracket to enclose several consecutive lines that are important, rather than underlining all of them; or a box or circle around key terms.

6) Review : Teachers should include regular review periods as an effective strategy for retaining information. . Students should study their outlines and notes and be able to retell what was read in their own words. Students should try to see relationships within the content. If they are unable to the teacher may need to model for students how to look for relationships. Student should be checking their memory by trying to recall main points and sub points (Richardson \& Morgan, 1997).

\section{The Principle in Teaching Reading Comprehension}

There are some principles that to be provided in the teaching of reading comprehension. They are :

1) Rreading is not a passive skill

2) Students need engaging in reading comprehension

3) Students should be encouraged to respond to the content of the reading text.

4) Predicting the message from the text

\section{Syllabus}

A syllabus is a document describing what must be learnt. This definition implies that it contains the materials prepared for the learner in the form of organization. Dubin and Olshtain ( $2002: 3$ ) write syllabus as a circumssribed document, usually one which has been prepared for particular group of learners. Based on the definitions, we can see that curriculum concerns a general rationale for formulating policy decision, which combines educational and cultural goals with language goals. Whereas, a syllabus is a document that contains specific elements aimed to actualize the concept of curriculum. The specific elements refer to all the things that are to be taught in the course.

Syllabus could be designed by teacher if he / she knows his / her learners' character, school condition, and he / she has understood the step of syllabus development on the other hand if the teacher is not be able do that, school can make group of teachers to develop the syllabus which will be used in their school but if a school can not design syllabus by itself, many schools can be collaborated to discuss how to develop it. The government has suggested the design of syllabus as in Government's rule no.19/ 2005 states :

\section{SYLLABUS}

Published by English Lecturers and Teachers Association (ELTA)

Copyright (C) 2021, authors 


\begin{tabular}{|c|c|}
\hline School & $:$ \\
\hline Subject & \\
\hline Class / semester & $: \ldots \ldots \ldots \ldots$ \\
\hline Competence Standard & $\therefore .$. \\
\hline
\end{tabular}

\begin{tabular}{|c|c|c|c|c|c|c|c|c|}
\hline \multirow{2}{*}{$\begin{array}{l}\text { Basic } \\
\text { Compe } \\
\text { Tence }\end{array}$} & \multirow[t]{2}{*}{ Materials } & \multirow{2}{*}{$\begin{array}{l}\text { Learn } \\
\text { ing } \\
\text { Activi } \\
\text { ties }\end{array}$} & \multirow{2}{*}{$\begin{array}{l}\text { Indica } \\
\text { tors }\end{array}$} & \multicolumn{3}{|c|}{ Assessment } & \multirow{2}{*}{$\begin{array}{l}\text { Time } \\
\text { Allocati } \\
\text { on }\end{array}$} & \multirow{2}{*}{$\begin{array}{l}\text { Sour } \\
\text { ce }\end{array}$} \\
\hline & & & & $\begin{array}{l}\text { Technique } \\
\text { of the } \\
\text { assess } \\
\text { ment }\end{array}$ & $\begin{array}{l}\text { The } \\
\text { Form of } \\
\text { the } \\
\text { assess } \\
\text { ment }\end{array}$ & $\begin{array}{l}\text { The } \\
\text { examp } \\
\text { le of } \\
\text { assess } \\
\text { ment }\end{array}$ & & \\
\hline 1 & 2 & 3 & 4 & 5 & 6 & 7 & 8 & 9 \\
\hline & & & & & & & & \\
\hline & & & & & & & & \\
\hline
\end{tabular}

Ccompetence Standard is the qualification of the students' ability in mastering the knowledge, attitudes and skills of the lesson, while materials of the lesson is the material that must be achieved by the students to master the basic competence..And indicators as the pattern in assessment which is arranged based on the characteristic of the school, potentials and the students or in the other words that indicators are as the tool of the teacher whether the students are able to master the materials that are being taught, the assessment should be arranged based on the indicators.

\section{Lesson Plan}

A lesson plan is a teacher's detailed description of the course of instruction for an individual lesson. A daily lesson plan is developed by a teacher to guide class instruction

In Depdiknas ( 2006 ) lesson plan is defined as a teacher's instruction do teaching learning process in class, laboratory and or in hall for every basic competence. To be a good teacher, he / she should manage the lesson plan by the following steps which described as follows :

\section{Write the Identity}

It includes many points such as :
1) School
2) Subject
3) Class / Semester.
4) The Standard of Competence

There are four competences based on 'Kurikulum Tingkat Satuan Pendidikan

(1) Listening, the students should comprehend meaning of simple interpersonal and transactional orally discourse, formally and informally, in recount, narrative, procedure, description and report form in daily life contexts.

(2) Speaking, state the meaning of simple interpersonal and transactional orally,formally and informally, in recount, narrative, procedure, description and report formin daily life contexts

(3) Reading, comprehend the meaning of simple interpersonal and transactional discourse / passages in recount, narrative, procedure, description and report form in daily life contexts

(4) Writing,state the meaning of simple interpersonal and transactional in written form, formally and informally, in recount, narrative, procedure, description and report formin daily life contexts

5) Basic competence 
Basic competence is the esential knowledge and skills acquired by students in relation to the learning targets and objectives set out in the curriculum for each key stage.

6) Standard Competence

Standard competence is known as the general objective and specific objective refers to the basic competence ; that is a minimal competence that learners possess in order to achieve the standard of competences provided. Standard of Competence : to communicate orally or in written form by using language model fluently and accurately in the interpersonal and / or monolog text in the form of narrative, descriptive, report, procedure and recount.

\section{List of Learning Outcomes}

Learning outcomes contains the mastering of operational competence which achieved in lesson plan. Learning outcomes are formulated in operational / behavioral statement from basic competence. If basic competence has been operational, these formulation would be basic learning outcomes formulation.

\section{List of the Material}

Learning material is the material which is used to attain learning outcomes. It can be improved based on prepared main material in syllabus. It is essential that teachers should master completely of what they are going to teach. It is equally important that they be up to date and acquainted technique and practices.

\section{List of the Method of teaching}

Method can be formulated as actual method but it can be formulated as model or instruction approach. It depends on the characteristic of chosen method and approach.

\section{List Istrument Steps.}

To achieve a basic competence, a teacher should write the step activity the each meeting. Basically, this activity of procedure can be divided into three steps, they are :

1) Opening activity

2) Main activity

3) Closing activity

\section{Learning Source}

In the past few years there has been a growing tendency amongs education list to shift from the traditional teacher - centered teaching to students - centered learning. It is believed that efficient instruction is more allied to the active participation than to passive participation of the learners. This shift in teaching - learning strategy calls for use of a variety of learning resources appropiate to the new strategy. Resource materials which are collected by the teacher should be managed regularly to the lesson plan. The resources that assist the teacher can be classified into planning documents and classroom material.

\section{Assessment}

Assessment includes technique, instrument form and uses instrument to collect data. Wragg ( 2001 : 7-56 ) classifies the assessment in two types, namely : Formal assessment and informal assessment.

1) Formal assessment is more structured examination that involves a standardized test, an examination paper, or an assessment schedule. Types of formal assessment are essay test and multiple choice

2) Informal assessment can take place in a varriety of setting and with very different purposes.

\section{School}

Lesson Plan Preparation sheet 
Subject : English

Class / Semester

A, Competence standard

B. Basic Competence

C. Kinds of Text

E. Theme

F. Skill

G. Time Allocation

1. The purpose of learning process

The characters which are going to achieve for example : Trustworthines, respect, diligence, responsibility and encouragement )

2. The Materials

3. The Methods

4. The steps of the process learning activities.

1) Pre- activity

2) Core- activity

3) Post - activity

5. Source

6. The assessment: a. Technique.

b. Form

c. Instrument

d. Score

Signed

The Principal of the school

( .......................)

Reg. Number of employee ( If owned )

\section{Research Methodology}

the method and the procedure to answer the problem of this research. The researcher used qualitative descriptiveanalysis, an experimental research. Methodology is a specific set of procedures. It explains the design, population, and technique for collecting data and data analysis.

\section{Data Analysis}

The data were collected after given the treatment. After the data were collected, the data were analyzed by identifying the real condition in the process of teaching Reading Comprehension. The researcher used qualitative analysis to analyze the data. The sum of the teachers are five English teachers from four junior high schools in Perbaungan. After analyzing the data, the writer found that two teachers used KWL Method, one teacher used PORPE Method, one teacher used Choral Reading Method and one teacher did not use a teaching method. The teachers applied the teaching method in their teaching learning process by following the steps of learning activities of the teaching method.

From the data analysis, the writer also found that three teachers who applied the teaching method in teaching reading process that relevance with the lesson plan and syllabus, one teacher who applied the Teaching Method in teaching learning process in teaching Reading Comprehension is not Relevance with the Lesson Plan but Relevance with Syllabus and one teacher who applied the Teaching Method in

Published by English Lecturers and Teachers Association (ELTA)

Copyright (C) 2021, authors 
teaching learning process in teaching Reading Comprehension is not Relevance with the Lesson Plan and Syllabus.

The writer also found thatthe teachers used the KWL Method in teaching Recount text and the PORPE method in teaching Narrative text. Two teachers applied the KWL method in teaching Recount Text and the method in teaching reading process is relevance with the lesson plan and syllabus result the mean of the students' achievement in reading comprehension is high and above KKM ( Kriteria Ketuntasan Minimal / Minimal Completeness Criteria). One teacher applied the PORPE method in teaching Narrative Text and the method in teaching reading process is relevance with the lesson plan and syllabus results the students' achievement in reading comprehension is high and above KKM ( Kriteria Ketuntasan Minimal / Minimal Completeness Criteria)

\section{Conclusion}

Two teachers used KWL Method, one teacher used PORPE Method, one teacher used Choral Reading Method and one teacher did not use a teaching Method in teaching Reading Comprehension.The teachers applied the teaching method in their teaching learning process by following the steps of learning activities of the teaching method.

Two teachers used KWL Method in teaching Recount text, one teacher used PORPE Method in teaching Narrative text and they applied their teaching methods in teaching learning process in teaching Reading Comprehension are relevance with Lesson Plan and Syllabus result the students' achievement in reading comprehension is high andabove KKM ( Kriteria Ketuntasan Minimal / Minimal Completeness Criteria), one teacher applied his teaching method in teaching learning process in teaching Reading Comprehension is not relevance with Lesson Plan and Syllabus and one teacher did not apply a teaching method in teaching learning process in teaching Reading Comprehension

\section{REFERENCES}

\section{DEPDIKNAS (2006) Panduan Penyusunan Kurikulum Tingkat Satuan Pendidikan Jenjang} Pendidikan Dasar dan Menengah. Jakarta : BNSP

Dubin, F., \& Olshtain, E. (1986). Course design: Developing programs and materials for language learning. Cambridge : Cambridge University press

Farrell, Thomas. 2009. Reading to English Language Learners. California: Corwin Press

Gadner R (2001) Language Learning. A Journal of Research in Language Studies. Volume 51 Number 1 March 2001. Cambridge University Press.

Gurning,Busmin (2008) Functional Academic Literacy in Teaching English . Journal of Linguistic Terapan Vol.5 no.2 November 2008. Program Studi Linguistic Terapan Bahasa Inggris

International reading association. (1999). Using multiple methods of beginning readinginstruction, a position statement of the international reading association. Newark, Delaware. USA

Jack C. Richards andTheodore S. Rodgers ( 1986)Cambridge LanguageTeaching Library Approaches and Methods In Language Teaching A description and analysis.

Mc.Neil J. D. (1992) Reading Comprehension New Direction for Classroom Practice (3rd ed ). Los Angeles: University of California

Published by English Lecturers and Teachers Association (ELTA)

Copyright (C) 2021, authors 
Journal of Applied Linguistics (JoAL), Vol. 1 No. 1, July 2021. e-ISSN 2809-1922, p-ISSN 2809-1914

Simpson, M. L., Stahl, N., \&Hayes, C. G. (1989). PORPE: A research validation. Journal ofReading, 33, 2228.

Thomas and Robinson (1972). Improving Reading in Every Class. Allyn and Bacon, Boston

Thornbury, Scott (2005), An A-Z of English Language Teaching. London; Macmilian Mayer

Topping, K. (1995). Paired reading, spelling and writing: The handbook for teachers andparents. Continuum International Publishing Group

Wragg. E. C (2001) Assesment and Learning in the Secondary School. London and New York Press

Wood, Tracy, M.Ed. 2006. Overcoming Dyslexia for Dummies. Indianapolis: Willey Publishing, 